\title{
Correction: Histamine is a modulator of metamorphic competence in Strongylocentrotus purpuratus (Echinodermata: Echinoidea)
}

Josh Sutherby ${ }^{1}$, Jamie-Lee Giardini ${ }^{1}$, Julia Nguyen ${ }^{1}$, Gary Wessel2 ${ }^{2}$, Mariana Leguia ${ }^{2,3}$ and Andreas Heyland ${ }^{1 *}$

In Figure six (Figure 1 here) of the original manuscript [1] panels B-H are representative images from which measurements were taken and then graphed in Figure six panel I. In the original submission of the manuscript panel $\mathrm{C}$ and $\mathrm{H}$ ended up showing identical images. We corrected this error by replacing panel $\mathrm{C}$ with the correct representative image. Note that this error occurred when preparing the original figure and it does not affect the data presented in any way.
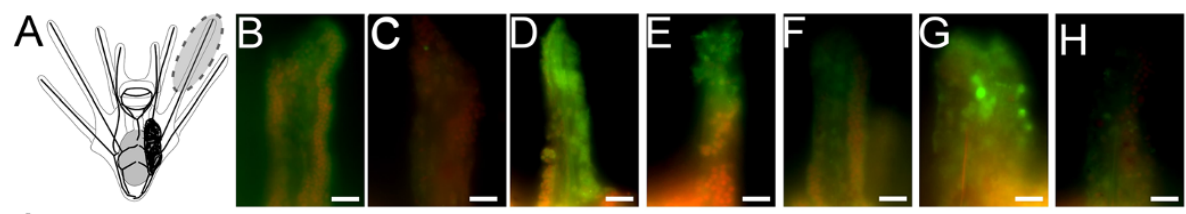

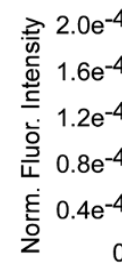
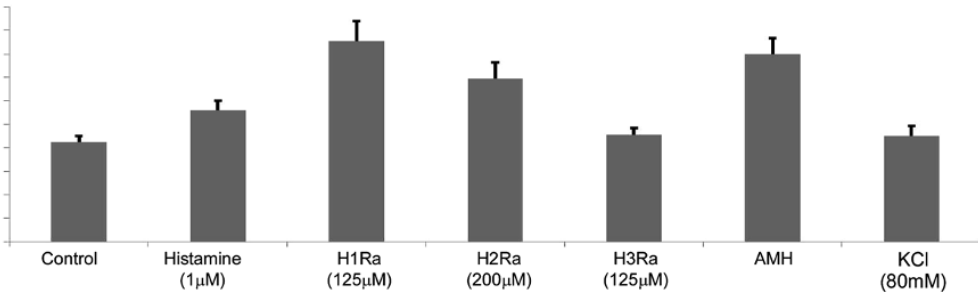

Figure 1 Histamine (HA) receptor 1 antagonist (125 $\mu \mathrm{M}$ chlorpheniramine) and histidine decarboxylase (HDC) inhibitor alphamethylhistidine (AMH, $100 \mu \mathrm{M}$ ) treatment of competent larvae leads to increased caspase activity. Caspase activity was analyzed using FAM-VAD-FMK, a fluorescently tagged caspase inhibitor. Normalized fluorescence was measured in the arm tips of competent larvae. HA, HA receptor 2 antagonist (200 $\mu \mathrm{M}$ cimetidine), HA receptor 3 antagonist (125 $\mu \mathrm{M}$ Thioperamide) and $\mathrm{KCl}$ had no effect on caspase activity. The upper panel shows representative fluorescent images of treatment categories: B-control, C-HA (1 $\mu \mathrm{M})$, D- HA receptor 1 antagonist $(125 \mu \mathrm{M}$ chlorpheniramine), E-HA receptor 2 antagonist (200 $\mu \mathrm{M}$ cimetidine), F-HA receptor 3 antagonist (125 $\mu \mathrm{M}$ Thioperamide), G-alpha-methylhistidine $(\mathrm{AMH}, 100 \mu \mathrm{M})$ and $\mathrm{H}-\mathrm{KCl}$. The lower panel shows the corresponding results of the fluorescent analysis. Panel A illustrates the approximate region of the arms that was included in the analysis. Note that all fluorescent intensities were normalized to the area measured and the exposure time. Scale bars: $20 \mu \mathrm{m}$.

\footnotetext{
*Correspondence: aheyland@uoguelph.ca

'University of Guelph, Integrative Biology, Guelph ON N1G-2 W1, Canada

Full list of author information is available at the end of the article
} 


\section{Author details}

${ }^{1}$ University of Guelph, Integrative Biology, Guelph ON N1G-2 W1, Canada.

${ }^{2}$ Brown University, MCB, Providence RI 02912, USA. ${ }^{3}$ Current address: U.S.

Naval Medical Research Unit No.6, Lima, Peru.

Received: 6 June 2013 Accepted: 12 June 2013

Published: 23 July 2013

\section{References}

1. Sutherby J, Giardini JL, Nguyen J, Wessel G, Leguia M, Heyland A: Histamine is a modulator of metamorphic competence in Strongylocentrotus purpuratus (Echinodermata: Echinoidea). BMC Dev Biol 2012, 12:14

doi:10.1186/1471-213X-13-30

Cite this article as: Sutherby et al:: Correction: Histamine is a modulator

of metamorphic competence in Strongylocentrotus purpuratus

(Echinodermata: Echinoidea). BMC Developmental Biology 2013 13:30.

\section{Submit your next manuscript to BioMed Central and take full advantage of:}

- Convenient online submission

- Thorough peer review

- No space constraints or color figure charges

- Immediate publication on acceptance

- Inclusion in PubMed, CAS, Scopus and Google Scholar

- Research which is freely available for redistribution 